\title{
HYDROGEN CONCENTRATION, CARBON DIOXIDE TENSION AND ACID BASE BALANCE IN BLOOD OF HUMAN UMBILICAL CORD AND INTERVILLOUS SPACE OF PLACENTA
}

BY

\author{
G. ROOTH, S. SJÖSTEDT and F. CALIGARA \\ From the Departments of Obstetrics and Gynaecology and Internal Medicine, University Hospital, Lund, \\ and the Wenner-Gren Cardiovascular Research Laboratory, Norrtull Hospital, Stockholm, Sweden
}

(RECEIVED FOR PUBLICATION JUNE 23, 1960)

In a previous paper (Sjöstedt, Rooth and Caligara, $1960)$ we reported on the oxygen tension $\left(\mathrm{pO}_{2}\right)$ in the blood of the human umbilical cord and the intervillous space of the placenta. It is the purpose of this paper to report on the $p \mathrm{H}$ and the carbon dioxide tension $\left(\mathrm{pCO}_{2}\right)$ in blood from the same sources in order to give a more complete picture of the gas exchange of the foetus and of its acid base balance.

\section{Material and Methods}

The cord blood was investigated in 222 cases after spontaneous delivery in vertex presentation; 154 of the infants were normal and without any signs of asphyxia before or after delivery; 46 had signs of asphyxia and 33 of these had slow or irregular heart beats during delivery but showed no signs of asphyxia after birth. The other 13 cases had signs of mild asphyxia after birth. In addition, 22 infants had meconium stained amniotic fluid without any other signs of asphyxia.

During labour the mothers were given 'trilene' (trichlorethylene) or nitrous oxide and in some cases a few drops of chloroform at the moment of delivery.

The blood in the intervillous space was investigated in 27 cases, 25 of which were normal and two of which had signs of mild toxaemia. The placenta was punctured through the abdominal wall before labour had started. Only local anaesthesia was used for the puncture and no complications occurred. The technique of the puncture has been described earlier by us (Sjöstedt et al., 1960).

Great care was taken to obtain reliable information about the time of gestation. Any case in which the duration of pregnancy was doubtful was rejected from the series on the effect of gestation time upon the $p \mathrm{H}$, $\mathrm{pCO}_{2}$ or $\mathrm{pO}_{2}$ of the blood.

The $\mathrm{pO}_{2}$ was measured polarographically with the Clark electrode as described by us (Rooth, Sjöstedt and Caligara, 1959a).

The $p \mathrm{H}$ was measured with a radiometer type $22 p \mathrm{H}$ meter and an Astrup apparatus. The temperature was kept at $37 \cdot 0^{\circ} \mathrm{C}$.

The $\mathrm{pCO}_{2}$ was measured by the Astrup method (1956). The principle is that the $p \mathrm{H}$ of the whole blood is first measured anaerobically. After centrifugation, the plasma is equilibrated with a gas of known $\mathrm{pCO}_{2}$ (close to $40 \mathrm{~mm}$. $\mathrm{Hg}$ ) and the $p \mathrm{H}$ is again measured. The $\mathrm{pCO}_{2}$ of the whole blood is then read off from the nomogram of Astrup (1956).

Standard bicarbonate buffer base (BB) and base excess (BE) are all terms which express the metabolic acid-base balance of the blood. In order to calculate those entities we used the nomogram of Siggaard Andersen and Engel (1960). Instead of measuring the haemoglobin in our cord blood we used a mean of $16.7 \mathrm{~g}$./ $100 \mathrm{ml}$. blood, a figure which was established in a previous study on 414 cord samples in this laboratory (Rooth and Sjöstedt, 1957b). This introduces an error in the calculations which, if the haemoglobin varies $\pm 4 \mathrm{~g} . / 100 \mathrm{ml}$. blood from $16.7 \mathrm{~g}$., will make about $\pm 1.3 \mathrm{mEq} /$ litre in BB, but scarcely any error in $\mathrm{BE}$ and standard bicarbonate.

As the cord blood contains a considerable amount of reduced haemoglobin which is more alkaline than oxyhaemoglobin, this must be taken into account and we have used the correction given by Siggaard Andersen and Engel (1960) according to which $10 \mathrm{~g}$. of reduced haemoglobin increases the BB $0.3 \mathrm{mEq}$. The oxygen saturation has been calculated from the $p \mathrm{H}$ and $\mathrm{pO}_{2}$ measurements with the help of the dissociation curve for the foetal blood established by us (Rooth et al., $1959 b$ ).

BB is the buffering protein of the blood + buffering bicarbonate. Henderson (1928) used this as an indicator of the metabolic acid base balance of the blood, but the term BB was introduced by Singer and Hastings (1948).

Standard bicarbonate is another indicator of the metabolic status introduced by Astrup (1956) and Jørgensen and Astrup (1957). Standard bicarbonate is the concentration of bicarbonate in plasma, when whole 


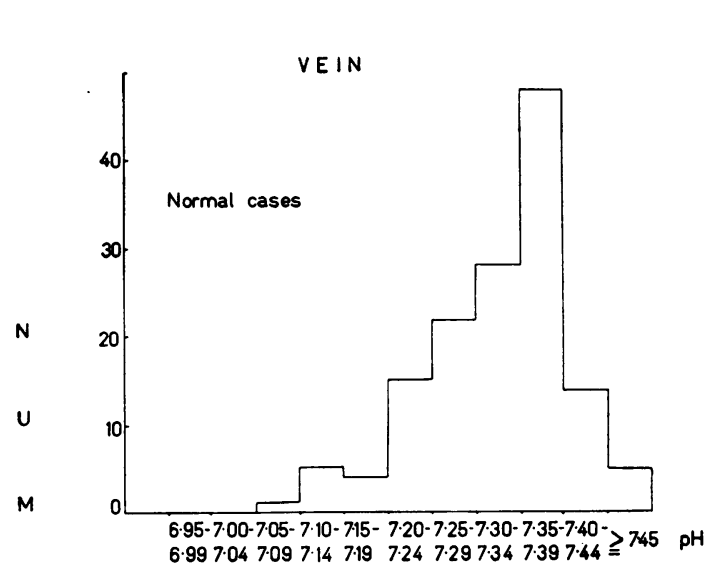

B

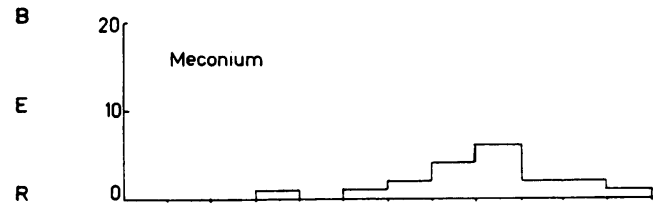

$\mathrm{pH}$

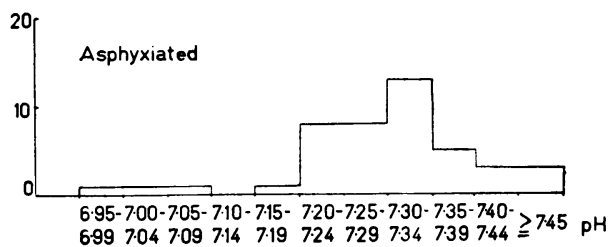

FIG. 1.-Distribution of the $p H$ in the umbilical vein in normal and asphyxiated infants and infants with meconium stained amniotic fluid.

blood has been equilibrated with carbon dioxide at a $\mathrm{pCO}_{2}$ of $40 \mathrm{~mm}$. $\mathrm{Hg}$ at $38^{\circ} \mathrm{C}$. and when the haemoglobin is fully oxygenated. The carbon dioxide-bicarbonate systems account for about $75 \%$ of the buffering action of the blood against fixed acid and bases.

$\mathrm{BE}$ is the same as normal BB minus the actual BB. The term BE was introduced by Astrup, Jørgensen, Siggaard Andersen and Engel (1960). Consequently $\mathrm{BE}$ directly expresses the excess in $\mathrm{mEq}$ of strong base or acid for every litre of blood, when the normal mean is arbitrarily fixed at zero. For the discussion of the relative merits of these different entities the reader is referred to the work of Astrup et al. (1960).

\section{Cord Blood}

\section{Results}

Hydrogen Concentration. The $p \mathrm{H}$ in the umbilical vein in 142 normal cases and in the arteries in 98 cases is given in Figs. 1 and 2 . These figures also give the $p \mathrm{H}$ in the vein of 44 cases grouped as asphyxiated and 30 measurements from the arteries

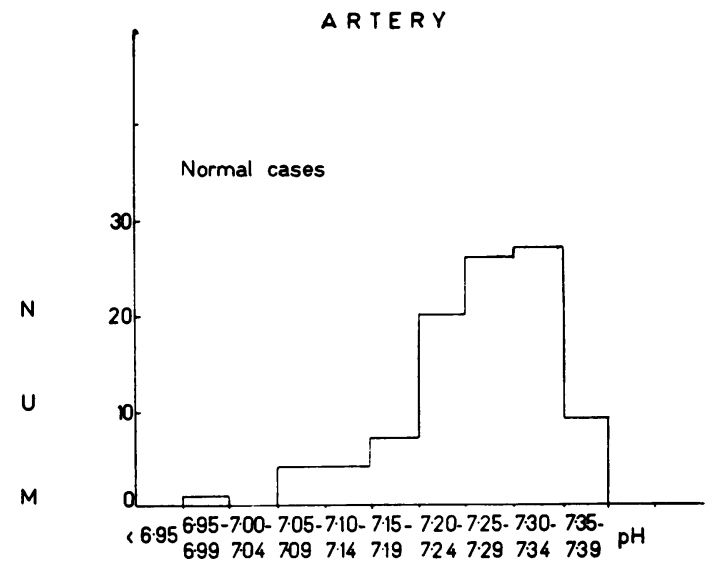

B
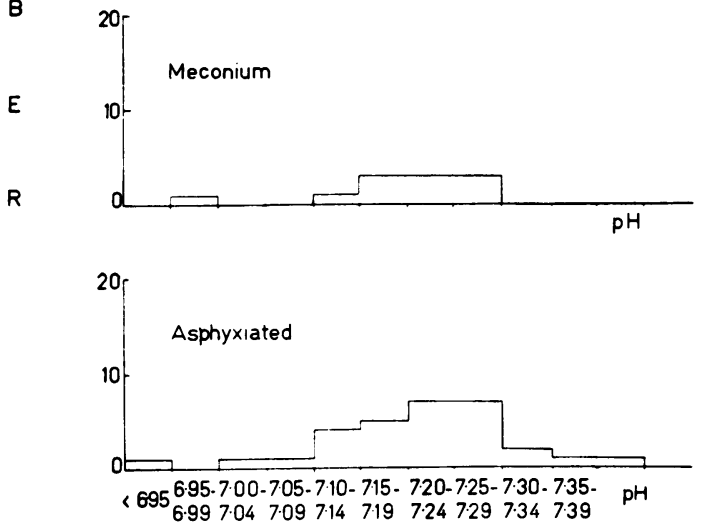

FIG. 2.-Distribution of the $p H$ in the umbilical arteries in normal and asphyxiated infants and infants with meconium stained amniotic fluid.

in the same group. Finally they also show the $p \mathrm{H}$ of the cases with meconium stained amniotic fluid. In this group measurements have been done in 18 cases in the vein and in 11 cases in the umbilical artery.

It will be observed that the $p \mathrm{H}$ is lower in the asphyxiated and meconium groups than in the normal cases (see also Table 2). In the normal ones, $54 \%$ of the cases have a $p \mathrm{H}$ in the vein which is lower than $7 \cdot 35$. In the meconium group this percentage is 72 and in the asphyxiated group 75 . In the arteries the $p \mathrm{H}$ is lower than $\mathbf{7 \cdot 2 5}$ in $37 \%$ of the normal cases, in $73 \%$ of the meconium group and in $63 \%$ of the asphyxiated group

Table 1 gives the $p \mathrm{H}$ and $\mathrm{pO}_{2}$ in the normal cases for different gestation weeks. The material has been divided into primigravidae and multigravidae. It will be seen that the $p \mathrm{H}$ may decrease in the umbilical arteries and vein when the gestation time is 42 weeks or more, but $\mathrm{pO}_{2}$ does not change with 
TABLE 1

MEAN HYDROGEN CONCENTRATION, CARBON DIOXIDE AND OXYGEN TENSION IN THE UMBILICAL CORD BLOOD AFTER NORMAL DELIVERY IN DIFFERENT GESTATION WEEKS

\begin{tabular}{|c|c|c|c|c|c|c|c|c|c|c|c|}
\hline & & & \multicolumn{9}{|c|}{ Gestation Week } \\
\hline & & & 36 & 37 & 38 & 39 & 40 & 41 & 42 & 43 & All \\
\hline $\begin{array}{l}\text { Artery: } \\
\quad \text { Primigravidae }\end{array}$ & $\begin{array}{l}p \mathrm{H} \\
\text { No. } \\
\text { pCO } \\
\text { No. } \\
\text { pO. } \\
\text { No. }\end{array}$ & $\begin{array}{l}\cdots \\
\cdots \\
\cdots \\
\cdots \\
\cdots\end{array}$ & $\begin{array}{c}7 \cdot 27 \\
2 \\
30 \\
1 \\
24 \\
2\end{array}$ & & $\begin{array}{l}7 \cdot 27 \\
2 \\
19 \\
2\end{array}$ & $\begin{array}{l}7 \cdot 22 \\
8 \\
44 \\
3 \\
21 \\
9\end{array}$ & $\begin{array}{l}7 \cdot 25 \\
16 \\
47 \\
5 \\
19 \\
15\end{array}$ & $\begin{array}{l}7 \cdot 26 \\
9 \\
45 \\
2 \\
19 \\
6\end{array}$ & $\begin{array}{l}7 \cdot 28 \\
4 \\
41 \\
3 \\
23 \\
8\end{array}$ & $\begin{array}{l}7 \cdot 24 \\
5 \\
57 \\
1 \\
19 \\
7\end{array}$ & $\begin{array}{l}7 \cdot 25 \\
46 \\
44 \\
15 \\
20 \\
49\end{array}$ \\
\hline Multigravidae & $\begin{array}{l}p \mathrm{H} \\
\text { No. } \\
\text { pCO } \\
\text { No. } \\
\text { po. } \\
\text { No. }\end{array}$ & $\begin{array}{l}\ldots \\
\cdots \\
\cdots \\
\cdots \\
\cdots\end{array}$ & & $\begin{array}{l}7 \cdot 34 \\
1 \\
31 \\
1\end{array}$ & $\begin{array}{l}7 \cdot 30 \\
2 \\
27 \\
1\end{array}$ & $\begin{array}{r}7 \cdot 26 \\
3 \\
38 \\
2 \\
18 \\
4\end{array}$ & $\begin{array}{c}7 \cdot 29 \\
16 \\
45 \\
6 \\
16 \\
18\end{array}$ & $\begin{array}{l}7 \cdot 29 \\
13 \\
51 \\
3 \\
16 \\
11\end{array}$ & $\begin{array}{c}7 \cdot 21 \\
7 \\
57 \\
1 \\
14 \\
9\end{array}$ & $\begin{array}{c}7 \cdot 19 \\
3 \\
49 \\
1 \\
14 \\
4\end{array}$ & $\begin{array}{l}7 \cdot 27 \\
45 \\
47 \\
13 \\
16 \\
48\end{array}$ \\
\hline All & $\begin{array}{l}p \mathrm{H} \\
\text { No. } \\
\text { pCO } \\
\text { No. } \\
\text { pOr } \\
\text { No. }\end{array}$ & $\begin{array}{l}\ldots \\
\ldots \\
\ldots \\
\ldots \\
\ldots\end{array}$ & $\begin{array}{l}7 \cdot 27 \\
2 \\
30 \\
1 \\
24 \\
2\end{array}$ & $\begin{array}{l}7 \cdot 34 \\
1 \\
31 \\
1\end{array}$ & $\begin{array}{c}7 \cdot 29 \\
4 \\
22 \\
3\end{array}$ & $\begin{array}{l}7 \cdot 23 \\
11 \\
41 \\
5 \\
20 \\
13\end{array}$ & $\begin{array}{l}7 \cdot 26 \\
32 \\
46 \\
11 \\
17 \\
33\end{array}$ & $\begin{array}{l}7 \cdot 28 \\
22 \\
49 \\
5 \\
17 \\
17\end{array}$ & $\begin{array}{c}7 \cdot 23 \\
11 \\
45 \\
4 \\
19 \\
17\end{array}$ & $\begin{array}{l}7 \cdot 22 \\
8 \\
53 \\
2 \\
17 \\
11\end{array}$ & $\begin{array}{l}7 \cdot 26 \\
91 \\
45 \\
28 \\
18 \\
97\end{array}$ \\
\hline $\begin{array}{l}\text { Vein: } \\
\text { Primigravidae }\end{array}$ & $\begin{array}{l}p \mathrm{H} \\
\text { No. } \\
\text { pCO.2 } \\
\text { No. } \\
\text { pO.2 } \\
\text { No. }\end{array}$ & $\begin{array}{l}\ldots \\
\ldots \\
\ldots \\
\ldots \\
\ldots\end{array}$ & $\begin{array}{l}7 \cdot 32 \\
2 \\
27 \\
1 \\
34 \\
2\end{array}$ & & $\begin{array}{l}7 \cdot 33 \\
3 \\
29 \\
2 \\
31 \\
2\end{array}$ & $\begin{array}{l}7 \cdot 31 \\
9 \\
37 \\
4 \\
30 \\
11\end{array}$ & $\begin{array}{l}7 \cdot 31 \\
19 \\
39 \\
7 \\
29 \\
18\end{array}$ & $\begin{array}{r}7 \cdot 32 \\
12 \\
43 \\
3 \\
29 \\
7\end{array}$ & $\begin{array}{c}7 \cdot 30 \\
8 \\
38 \\
4 \\
33 \\
9\end{array}$ & $\begin{array}{l}7 \cdot 28 \\
9 \\
39 \\
5 \\
30 \\
8\end{array}$ & $\begin{array}{l}7 \cdot 31 \\
62 \\
38 \\
26 \\
30 \\
57\end{array}$ \\
\hline Multigravidae & $\begin{array}{l}p \mathrm{H} \\
\text { No. } \\
\text { pCO } \\
\text { No. } \\
\text { po. } \\
\text { No. }\end{array}$ & $\begin{array}{l}\ldots \\
\ldots \\
\cdots \\
\ldots \\
\cdots\end{array}$ & $\begin{array}{l}7 \cdot 38 \\
1 \\
33 \\
1 \\
33 \\
1\end{array}$ & $\begin{array}{c}7 \cdot 40 \\
1 \\
43 \\
1\end{array}$ & $\begin{array}{l}7 \cdot 34 \\
3 \\
38 \\
2 \\
33 \\
2\end{array}$ & $\begin{array}{c}7 \cdot 33 \\
6 \\
37 \\
3 \\
27 \\
7\end{array}$ & $\begin{array}{l}7 \cdot 35 \\
23 \\
36 \\
8 \\
27 \\
23\end{array}$ & $\begin{array}{c}7 \cdot 36 \\
20 \\
34 \\
6 \\
31 \\
19\end{array}$ & $\begin{array}{c}7 \cdot 31 \\
9 \\
43 \\
2 \\
26 \\
11\end{array}$ & $\begin{array}{r}4 \cdot 27 \\
48 \\
2 \\
30 \\
4\end{array}$ & $\begin{array}{l}7 \cdot 34 \\
67 \\
37 \\
24 \\
28 \\
68\end{array}$ \\
\hline All & $\begin{array}{l}p \mathrm{H} \\
\text { No. } \\
\text { pCO. } \\
\text { No. } \\
\text { pO.; } \\
\text { No. }\end{array}$ & $\begin{array}{l}\cdots \\
\cdots \\
\cdots \\
\cdots \\
\cdots\end{array}$ & $\begin{array}{l}7 \cdot 34 \\
3 \\
30 \\
2 \\
34 \\
3\end{array}$ & $\begin{array}{c}7 \cdot 40 \\
1 \\
43 \\
1\end{array}$ & $\begin{array}{l}7 \cdot 34 \\
6 \\
33 \\
4 \\
32 \\
4\end{array}$ & $\begin{array}{l}7 \cdot 32 \\
15 \\
37 \\
7 \\
29 \\
18\end{array}$ & $\begin{array}{l}7 \cdot 33 \\
42 \\
38 \\
15 \\
28 \\
41\end{array}$ & $\begin{array}{l}7 \cdot 35 \\
32 \\
37 \\
9 \\
30 \\
26\end{array}$ & $\begin{array}{c}7 \cdot 31 \\
17 \\
40 \\
6 \\
29 \\
20\end{array}$ & $\begin{array}{l}7 \cdot 27 \\
13 \\
41 \\
7 \\
30 \\
12\end{array}$ & $\begin{array}{c}7 \cdot 32 \\
129 \\
38 \\
50 \\
29 \\
125\end{array}$ \\
\hline
\end{tabular}

TABLE 2

MEAN OXYGEN TENSION, HYDROGEN CONCENTRATION, CARBON DIOXIDE TENSION, STANDARD BICARBONATE, BUFFER BASE AND BASE EXCESS IN THE UMBILICAL CORD BLOOD AFTER NORMAL DELIVERY OR AFTER DELIVERY WITH DIFFERENT SIGNS OF ASPHYXIA

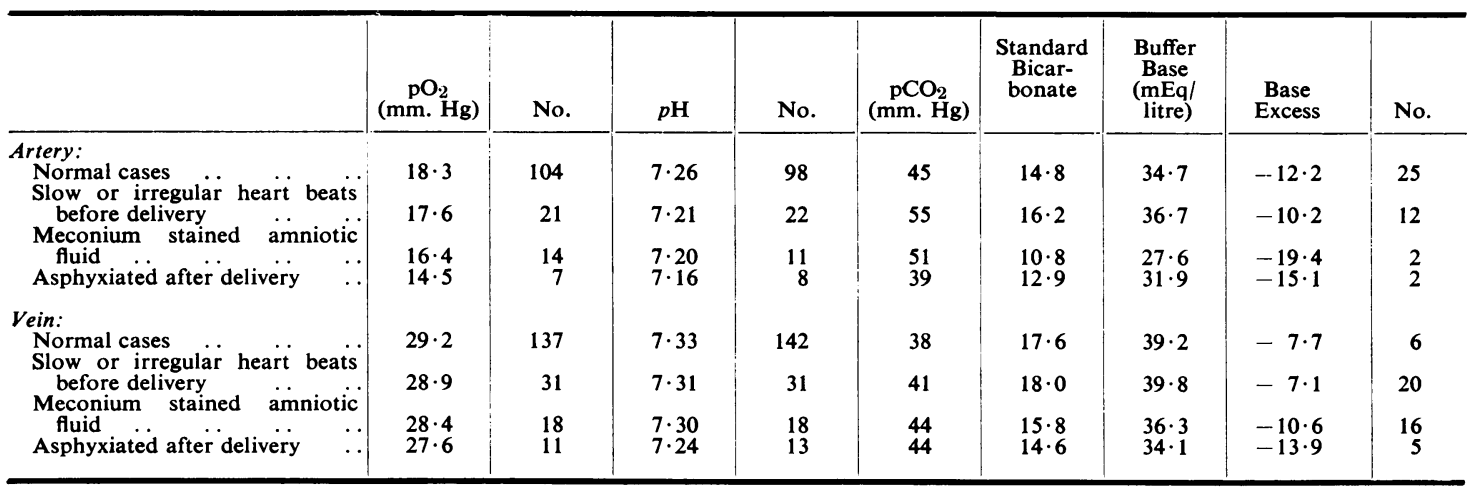




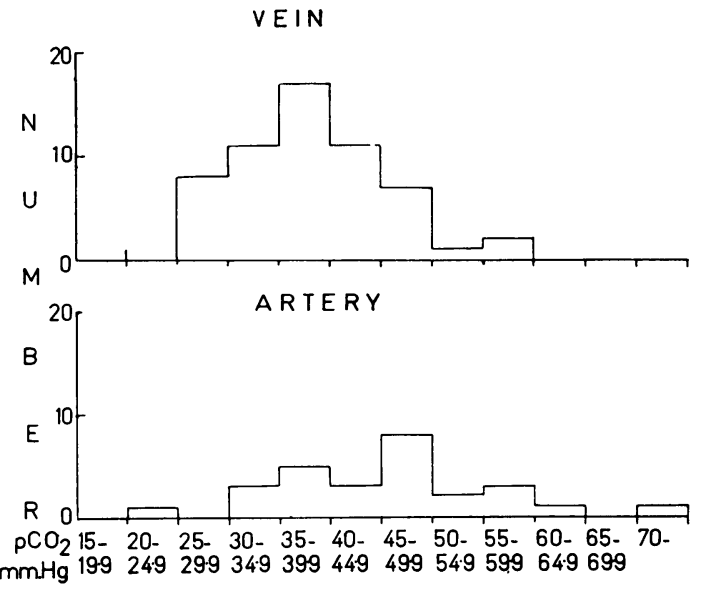

FIG. 3.-Distribution of the $\mathrm{pCO}_{2}$ in the umbilical vein and arteries of normal infants.

advancing gestation time, a fact which has been shown by us previously (Sjöstedt et al., 1960). There is also a tendency for the $p \mathrm{H}$ to be lower in primigravidae than in multigravidae.

Carbon Dioxide Tension. The distribution of the $\mathrm{pCO}_{2}$ values in the cord blood of the normal cases is shown in Fig. 3. The mean values of $\mathrm{pO}_{2}, p \mathrm{H}$ and $\mathrm{pCO}_{2}$ are given in Table 2 for the normal cases and the groups with various signs of asphyxia. The first group had slow or irregular heart beats before the delivery, but no signs of asphyxia after birth. The second group had meconium stained amniotic fluid, but no other signs of asphyxia before or after birth. The third group showed signs of asphyxia after the delivery, manifested by diminished muscular tonus and/or delayed onset of spontaneous respiration. No case of severe asphyxia was studied in this series.

It will be observed that $\mathrm{pCO}_{2}$ in the umbilical arteries and vein is higher in the asphyxiated than in the normal cases. The asphyxiated cases also have reduced $\mathrm{pO}_{2}$ and $\mathrm{pH}$. The changes are of about the same magnitude in the arteries and the vein though perhaps a little more pronounced in the arteries.

Although the number of observations in the different gestation weeks is small there seems to be an increase of the $\mathrm{pCO}_{2}$ in the umbilical vein blood with advancing gestation. No such increase can be observed in the arteries.

Acid Base Balance. The distribution of the standard bicarbonate and $\mathrm{BB}$ in 56 normal cases from the vein and in 25 normal cases from the arteries is given in Fig. 4. The mean values for the metabolic acid base balance are shown in Table 2. The number of pathological cases is small especially in the arteries. There is a metabolic acidosis in the infants asphyxiated after birth and in those with meconium stained amniotic fluid.

BUFFER BASE

VEIN

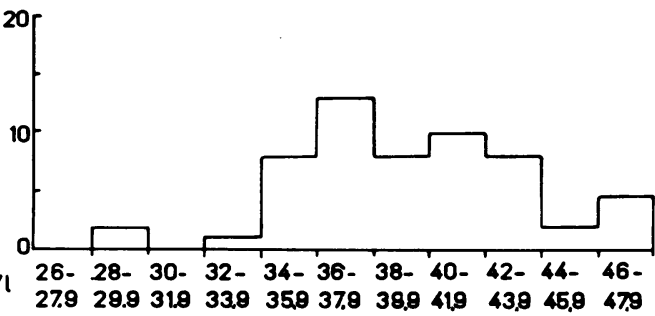

ARTERY

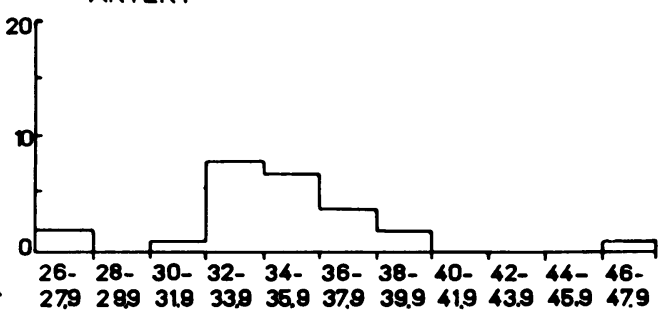

Fig. 4.-Distribution of standard bicarbonate and buffer base in the vein and arteries of normal infants. 


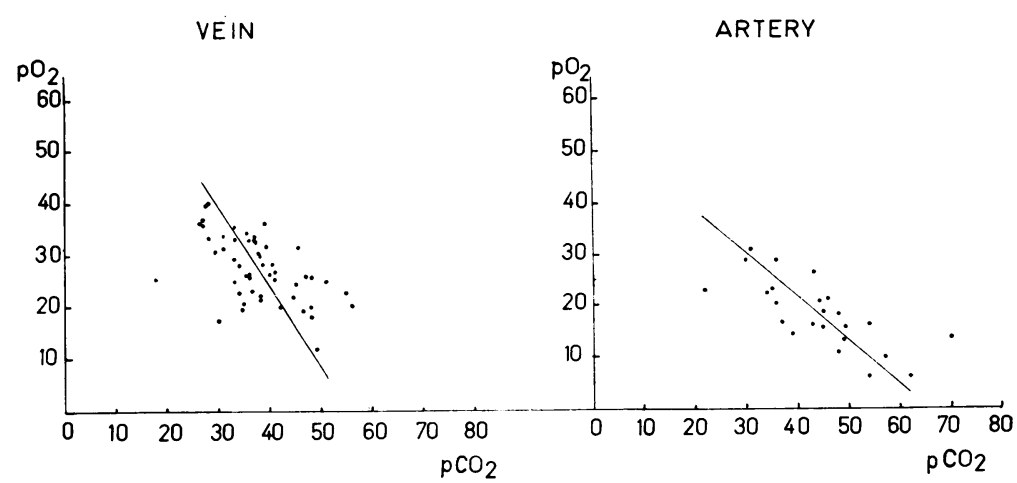

Fig. 5.-The relation between $\mathrm{pCO}_{2}$ and $\mathrm{pO}_{2}$ in the umbilical vein and arteries of normal infants.
The relation between the $\mathrm{pO}_{2}$ and $\mathrm{pCO}_{2}$ in the umbilical vein and arteries is given in Fig. 5. It will be seen that if the $\mathrm{pO}_{2}$ decreases, the $\mathrm{pCO}_{2}$ increases, as would be expected in any situation which obstructs the normal passage of gas from the mother and vice versa.

Intervillous Blood of the Placenta. The figures for the $\mathrm{pO}_{2}, p \mathrm{H}, \mathrm{pCO}_{2}$ and the metabolic acid base balance in 27 samples from the intervillous blood of the placenta are given in Table 3. Compared with the umbilical blood, the intervillous blood has higher $\mathrm{pO}_{2}, p \mathrm{H}$, standard bicarbonate and $\mathrm{BB}$. The $\mathrm{pCO}_{2}$ is lower than in the umbilical artery and the same as in the umbilical vein.

\section{Discussion}

Hydrogen Concentration. The present investigation corroborates and extends knowledge about the $p \mathrm{H}$ of the cord blood. A detailed discussion of earlier works has recently been published by Kaiser (1959). Table 4 shows the $p \mathrm{H}$ values available in the literature after 1932.

These studies have established that the $p \mathrm{H}$ of the umbilical arteries is lower than that of the umbilical vein. The $p \mathrm{H}$ of the umbilical vein in its turn is lower than that of the maternal vein and artery. In this respect it is perhaps better to make a comparison with the $p \mathrm{H}$ of the intervillous blood, which we have found to be $7 \cdot 41$ against $7 \cdot 33$ for the

TABLE 3

OXYGEN TENSION, HYDROGEN CONCENTRATION, CARBON DIOXIDE TENSION, STANDARD BICARBONATE, BUFFER BASE AND BASE EXCESS IN THE INTERVILLOUS BLOOD OF THE PLACENTA

\begin{tabular}{|c|c|c|c|c|c|c|}
\hline Case & $\left.\underset{(\mathrm{mm} .}{\mathrm{pO}_{2}} \mathbf{H g}\right)$ & $p \mathbf{H}$ & $\underset{(\mathrm{mm} . \mathrm{Hg})}{\mathrm{pCO}}$ & $\begin{array}{c}\text { Standard } \\
\text { Bicarbonate }\end{array}$ & $\begin{array}{c}\text { Buffer Base } \\
\text { (mEq/litre) }\end{array}$ & Base Excess \\
\hline $\begin{array}{r}1 \\
2 \\
3 \\
4 \\
5 \\
6 \\
7 \\
8 \\
9 \\
10 \\
11 \\
12 \\
13 \\
14 \\
15 \\
16 \\
17 \\
18 \\
19 \\
20 \\
21 \\
22 \\
23 \\
24 \\
25 \\
26 \\
27\end{array}$ & $\begin{array}{l}36 \\
30 \\
30 \\
43 \\
54 \\
36 \\
48 \\
34 \\
33 \\
36 \\
51 \\
38 \\
48 \\
46 \\
35 \\
48 \\
28 \\
48 \\
50 \\
35 \\
40 \\
41 \\
37 \\
45 \\
37\end{array}$ & $\begin{array}{l}7 \cdot 37 \\
7 \cdot 32 \\
7 \cdot 35 \\
7 \cdot 45 \\
7 \cdot 42 \\
7 \cdot 41 \\
7 \cdot 40 \\
7 \cdot 33 \\
7 \cdot 39 \\
7 \cdot 44 \\
7 \cdot 36 \\
7 \cdot 43 \\
7 \cdot 41 \\
7 \cdot 39 \\
7 \cdot 43 \\
7 \cdot 42 \\
7 \cdot 40 \\
7 \cdot 39 \\
7 \cdot 40 \\
7 \cdot 40 \\
7 \cdot 39 \\
7 \cdot 43 \\
7 \cdot 44 \\
7 \cdot 45 \\
7 \cdot 47 \\
7 \cdot 44\end{array}$ & $\begin{array}{l}43 \\
38 \\
38 \\
27 \\
29 \\
48 \\
43 \\
48 \\
36 \\
38 \\
34 \\
38 \\
34 \\
38 \\
37 \\
38\end{array}$ & $\begin{array}{l}22 \\
24 \\
23 \\
18 \\
20 \\
28 \\
25 \\
25 \\
22 \\
23 \\
20 \\
23 \\
23 \\
25 \\
26 \\
25\end{array}$ & $\begin{array}{l}44 \\
47 \\
45 \\
38 \\
41 \\
51 \\
47 \\
49 \\
45 \\
45 \\
42 \\
45 \\
46 \\
49 \\
52 \\
47\end{array}$ & $\begin{array}{r}-1 \\
+2 \\
0 \\
-7 \\
-4 \\
+7 \\
+3 \\
+3 \\
-1 \\
0 \\
-4 \\
-1 \\
0 \\
+3 \\
+4 \\
+2\end{array}$ \\
\hline $\begin{array}{l}\text { Mean .. } \\
\text { Mean umbilical artery } \\
\text { Mean umbilical vein }\end{array}$ & $\begin{array}{l}40 \\
18 \\
29\end{array}$ & $\begin{array}{l}7 \cdot 41 \\
7 \cdot 26 \\
7 \cdot 33\end{array}$ & $\begin{array}{l}38 \\
45 \\
38\end{array}$ & $\begin{array}{l}23 \cdot 2 \\
14 \cdot 8 \\
17 \cdot 6\end{array}$ & $\begin{array}{l}45 \cdot 8 \\
34 \cdot 7 \\
39 \cdot 2\end{array}$ & $\begin{array}{l}+0 \cdot 3 \\
-12 \cdot 2 \\
-7 \cdot 7\end{array}$ \\
\hline
\end{tabular}


TABLE 4

SURVEY OF UMBILICAL CORD BLOOD $p$ H STUDIES

\begin{tabular}{|c|c|c|c|c|c|c|}
\hline \multirow{2}{*}{\multicolumn{3}{|c|}{ Author }} & \multicolumn{2}{|c|}{ Artery } & \multicolumn{2}{|c|}{ Vein } \\
\hline & & & $p \mathrm{H}$ & No. & $p \mathrm{H}$ & No. \\
\hline $\begin{array}{l}\text { Normal cases: } \\
\text { Eastman (1932) . } \\
\text { Noguchi (1937) } \\
\text { Kaiser (1953) } \\
\text { Goodlin and Kaise } \\
\text { James et al. (1958) } \\
\text { Kaiser and Goodli } \\
\text { MacKinney et al. } \\
\text { Wulf (1959a) } \\
\text { Wulf (1959b) } \\
\text { Present series }\end{array}$ & $\begin{array}{c}\ldots \\
\cdots \\
957) \\
938) \\
8) \\
\ldots \\
\ldots \\
\ldots\end{array}$ & $\begin{array}{c}. . \\
. \\
. \\
. \\
. \\
. \\
. \\
. .\end{array}$ & $\begin{array}{l}7 \cdot 33 \\
7 \cdot 32 \\
7 \cdot 26 \\
7 \cdot 28\end{array}$ & $\begin{array}{r}3 \\
14 \\
12 \\
28\end{array}$ & $\begin{array}{l}7 \cdot 36 \\
7 \cdot 36 \\
7 \cdot 32 \\
7 \cdot 32 \\
7 \cdot 26 \\
7 \cdot 34 \\
7 \cdot 29 \\
7 \cdot 35 \\
7 \cdot 41 \\
7 \cdot 33\end{array}$ & $\begin{array}{r}8 \\
14 \\
12 \\
28 \\
30 \\
25 \\
200 \\
40 \\
36 \\
142\end{array}$ \\
\hline $\begin{array}{c}\text { Asphyxiated cases: } \\
\text { Eastman (1932) } \\
\text { Noguchi (1937) } \\
\text { James et al. (1958) } \\
\text { Wulf (1959) } \\
\text { Present series }\end{array}$ & $\begin{array}{l}\cdots \\
\because \\
\cdots \\
\cdots\end{array}$ & $\begin{array}{c}\because \\
\because \\
\cdots\end{array}$ & $\begin{array}{l}7 \cdot 04 \\
7 \cdot 18 \\
7 \cdot 20\end{array}$ & $\begin{array}{l}10 \\
20 \\
41\end{array}$ & $\begin{array}{l}7 \cdot 04 \\
7 \cdot 24 \\
7 \cdot 23 \\
7 \cdot 29\end{array}$ & $\begin{array}{r}6 \\
7 \\
20 \\
62\end{array}$ \\
\hline
\end{tabular}

umbilical vein. It will be seen from Fig. 1 that there are more cases with a $p \mathrm{H}$ between 7.35 and $7 \cdot 40$ than in any other group. Thus the $p \mathrm{H}$ difference between the intervillous maternal blood and the umbilical vein is small in normal cases. The $p \mathrm{H}$ of foetal blood increases during its passage through the placenta, indicating that this blood is giving up carbon dioxide and/or fixed acids. This will be discussed later.

The highest mean $p \mathrm{H}$ values in the umbilical vein given in the literature are those of Wulf (1959b), Eastman (1932) and Noguchi (1937). Wulf gives the high value of $7 \cdot 41$ and the others give $7 \cdot 36$. Noguchi also has the highest value in the umbilical artery, i.e. 7·32. The largest series (MacKinney, Goldberg, Ehrlich and Freymann, 1958) consisting of 200 cases before respiration has a mean of only 7.29. Most of the investigators have a mean of about $7 \cdot 32$. These variations are probably due, in the main, to differences in technique, particularly in the $p \mathrm{H}$ standard, and in material. If the $p \mathrm{H}$ is high and the technique sound, this indicates that the cases are normal and the $p \mathrm{H}$ values represent the true intrauterine figures.

Kaiser (1959), in his review, states that no information is available about alkalosis in the umbilical cord blood. It is true that the figures so far discussed are those of a mild acidosis. It must be remembered, however, that this expression is used solely because the $p \mathrm{H}$ is lower than the conventionally given figure for adult arterial blood and that the term acidosis in this sense has no pathological significance. As seen from Fig. 1, in 24 venous samples we have found a $p \mathrm{H}$ of 7.40 and above. In comparison with the mean $p \mathrm{H}$ of the umbilical vein this may be called alkalosis. In 40 normal cases Wulf (1959a) found eight with a $p H$ higher than $7 \cdot 40$, i.e. about $20 \%$ of the total cases, as in the present series. The foetus cannot decrease its $\mathrm{pCO}_{2}$ and thereby increase the $p \mathrm{H}$ as the respiring individual does. The only way for the foetus to achieve this is if the $\mathrm{pCO}_{2}$ of the intervillous blood decreases, i.e. by hyperventilation of the mother. This also occurs during labour and values of arterial maternal $\mathrm{pCO}_{2}$ of less than $30 \mathrm{~mm}$. $\mathrm{Hg}$ have been found by Boutourline-Young and BoutourlineYoung (1956) and Weisbrot, James, Prince, Holaday and Apgar (1958).

If the infant is asphyxiated the $p \mathrm{H}$ is reduced in the umbilical arteries and vein. This decrease in $p \mathrm{H}$ is first seen in the arteries (Table 2). In the umbilical vein the $p \mathrm{H}$ is reduced particularly in those cases showing definite signs of asphyxia after birth. The $p \mathrm{H}$ is then about $0 \cdot 1$ units lower than the normal mean. As seen in Table 4, Eastman (1932) and James, Weisbrot, Prince, Holaday and Apgar (1958) report much lower values. The reason is that these authors analysed cases with severe asphyxia, whereas our cases were only mild. A few of our asphyxiated infants as well as a few of our normal infants have shown very low $p \mathrm{H}$ values (Figs. 1 and 2). Very low values even in vigorous infants have also been found in cord blood oxygen saturation studies and have been discussed earlier by us (Rooth and Sjöstedt, 1957a).

As seen in Table 1, there is a tendency for the $p \mathrm{H}$ to be lower in the cord blood of the primigravidae than in that of the multigravidae. As the $\mathrm{pCO}_{2}$ is the same, this could be explained by more difficult labour during which the mother and/or the foetus has increased production of lactic acid and other fixed acids.

Carbon Dioxide Tension. Tables 5 and 6 give a survey of some $\mathrm{pCO}_{2}$ and oxygen saturation values available in the literature. A survey of $\mathrm{pO}_{2}$ values has earlier been given by us (Sjöstedt et al., 1960). It can be seen from these Tables that our material, whether earlier or from the present series, shows high $\mathrm{pO}_{2}$ or oxygen saturation values and low $\mathrm{pCO}_{2}$ values. Our $p \mathrm{H}$ values are of the same magnitude as those established by others, suggesting that our cases are perhaps nearer to normal than those studied by others. This has a special interest in view of the fact that many authors are very cautious about figures obtained from cord blood drawn after delivery. The higher the $\mathrm{pO}_{2}$ and oxygen saturation and the lower the $\mathrm{pCO}_{2}$ the higher the probability that the figures represent the original intrauterine conditions. It seems reasonable to assume that the true intrauterine level for the $\mathrm{pCO}_{2}$ is about $40 \mathrm{~mm}$. $\mathrm{Hg}$ for the umbilical artery. 
TABLE 5

SURVEY OF UMBILICAL CORD BLOOD $\mathrm{pCO}_{2}$ STUDIES

\begin{tabular}{|c|c|c|c|c|c|}
\hline \multirow{2}{*}{\multicolumn{2}{|c|}{ Author }} & \multicolumn{2}{|c|}{ Artery } & \multicolumn{2}{|c|}{ Vein } \\
\hline & & $\begin{array}{c}\mathrm{pCO}_{2} \\
(\mathrm{~mm} . \mathrm{Hg})\end{array}$ & No. & $\begin{array}{c}\mathrm{pCO}_{2} \\
(\mathrm{~mm} . \mathrm{Hg})\end{array}$ & No. \\
\hline $\begin{array}{l}\text { Haselhorst and } \\
\text { (1931) } \\
\text { Eastman (1932) } \\
\text { Beer } \text { et al. (1955) } \\
\text { Goodlin and Ka } \\
\text { James et al. (195 } \\
\text { MacKinney et al. } \\
\text { Wulf (1959a) . } \\
\text { Wulf (1959b) . } \\
\text { Present series . }\end{array}$ & 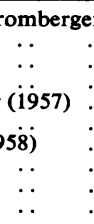 & $\begin{array}{l}50 \\
42 \\
60 \\
53 \\
55\end{array}$ & $\begin{array}{r}4 \\
3 \\
20 \\
11 \\
27 \\
\\
\\
36 \\
27\end{array}$ & $\begin{array}{l}36 \\
45 \\
42 \\
48 \cdot 5 \\
44 \\
44 \\
38\end{array}$ & $\begin{array}{r}8 \\
20 \\
11 \\
189 \\
40 \\
36 \\
58\end{array}$ \\
\hline
\end{tabular}

TABLE 6

SURVEY OF UMBILICAL CORD BLOOD OXYGEN SATURATION STUDIES

\begin{tabular}{|c|c|c|c|c|}
\hline \multirow{2}{*}{ Author } & \multicolumn{2}{|c|}{ Artery } & \multicolumn{2}{|l|}{ Vein } \\
\hline & $\begin{array}{c}\text { Oxygen } \\
\text { Saturation }\end{array}$ & No. & $\begin{array}{c}\text { Oxygen } \\
\text { Saturation }\end{array}$ & No. \\
\hline 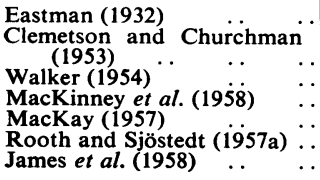 & $\begin{array}{l}16 \\
31 \\
20 \\
24 \\
30 \\
34 \\
22\end{array}$ & $\begin{array}{r}15 \\
10 \\
9 \\
234 \\
112 \\
172 \\
43\end{array}$ & $\begin{array}{l}50 \\
63 \\
48 \\
48 \\
64 \\
62 \\
49\end{array}$ & $\begin{array}{r}15 \\
12 \\
10 \\
286 \\
112 \\
225 \\
55\end{array}$ \\
\hline
\end{tabular}

The arteriovenous difference in $\mathrm{pCO}_{2}$ of about $7 \mathrm{~mm}$. $\mathrm{Hg}$ is a measure of the carbon dioxide given up to the maternal circulation in the placenta. In 26 cases we have found the $\mathrm{pCO}_{2}$ of the intervillous blood of the placenta to be on an average $40 \mathrm{~mm}$. $\mathrm{Hg}$ or identical with that of the foetal $\mathrm{pCO}_{2}$ of the umbilical vein. These figures indicate an almost complete exchange of $\mathrm{CO}_{2}$ across the placenta as opposed to the oxygen transport. The difference in $\mathrm{pO}_{2}$ is about $10 \mathrm{~mm} . \mathrm{Hg}$ (Sjöstedt et al., 1960). These differences between oxygen and carbon dioxide are to be expected from the higher diffusion coefficient for carbon dioxide.

No previous comparison seems to have been made between the intervillous $\mathrm{pCO}_{2}$ and the $\mathrm{pCO}_{2}$ of the foetal circulation in man. Beer, Bartels and Raczkowski (1955) assume for their calculations a complete equilibration. In animals with a syndesmochorial placenta five layers thick such as cows and sheep, pressure differences of about $20 \mathrm{~mm}$. $\mathrm{Hg}$ have been found (Roos and Romijn, 1940). In rabbits with a haemoendothelial placenta, Young (1952) has observed values between 14 and $-2 \mathrm{~mm}$. $\mathrm{Hg}$.

Darling, Smith, Asmussen and Cohen (1941) calculated the relation between $p \mathrm{H}$ and $\mathrm{pO}_{2}$ if the $p \mathrm{H}$ of the foetal blood is changed by varying the $\mathrm{pCO}_{2}$. Consequently there is a relation between $\mathrm{pCO}_{2}$ and $\mathrm{pO}_{2}$ and this is evident also from Fig. 5. There is a large scatter in these figures as might be expected because we are dealing with individual blood samples and not systematic $\mathrm{pCO}_{2}$ or $\mathrm{pO}_{2}$ changes in one and the same blood. It will be observed, however, that even when $\mathrm{pCO}_{2}$ rises to high levels, the $\mathrm{pO}_{2}$ is usually maintained, although at a relatively low level. As a rule these cases have a metabolic acidosis and they demonstrate how the $\mathrm{pO}_{2}$ is kept up at all costs.

Acid Base Balance. Compared with the mother the foetus has a metabolic acidosis (Table 3) and it can be seen that in comparison with the umbilical vein, the umbilical artery has a metabolic acidosis (Table 3 and Fig. 4). Expressed in BB the mean difference between the arteries and the vein is about $4.5 \mathrm{mEq} / \mathrm{litre}$. This difference is a measure of the fixed acids which pass from the foetal to the maternal circulation. Once pulmonary ventilation starts after birth the BB of the arteries and the veins is similar to that in adult blood. Because of the error inherent in our way of estimating the metabolic acid base balance, the present series cannot be used for an exact determination of the normal values in cord blood, but the values are of the same order as those of James et al. (1958).

As already shown by Eastman (1932) the slightly asphyxiated foetus compared with the normal foetus has no metabolic acidosis, whereas those with more pronounced asphyxia have low bicarbonate content as a sign of metabolic acidosis. These findings are confirmed and expressed in the more exact form of BB by James et al. (1958). Our material is small but the same tendency is present.

\section{Summary}

The cord blood of 222 infants has been analysed for $p \mathrm{H}, \mathrm{pCO}_{2}, \mathrm{pO}_{2}$ and metabolic acid base balance expressed as standard bicarbonate, $\mathrm{BB}$ and $\mathrm{BE}$.

From the placenta 26 samples of intervillous blood have been analysed in the same way and the results are compared with the cord blood in order to show the gas exchange of the foetus.

The mean $p \mathrm{H}$ after normal delivery is $7 \cdot 26$ in the umbilical artery and 7.33 in the umbilical vein.

The mean $\mathrm{pCO}_{2}$ after normal delivery is $45 \mathrm{~mm}$. $\mathrm{Hg}$ in the umbilical artery and $38 \mathrm{~mm}$. $\mathrm{Hg}$ in the vein.

The mean BB after normal delivery is $35 \mathrm{mEq} /$ litre in the umbilical artery and $39 \mathrm{mEq} / \mathrm{litre}$ in the vein, indicating that during the passage through the placenta the foetal blood gives up fixed acids to the maternal circulation. 
In the intervillous blood of the placenta the mean $p \mathrm{H}$ is $7 \cdot 41$, the mean $\mathrm{pCO}_{2} 38 \mathrm{~mm}$. $\mathrm{Hg}$ and the mean BB $46 \mathrm{mEq} /$ litre.

The $\mathrm{pCO}_{2}$ in the umbilical vein and the intervillous space of the placenta are the same, $38 \mathrm{~mm}$. $\mathrm{Hg}$, indicating an almost complete exchange of carbon dioxide between the foetal and maternal circulation.

This study was supported by grants from the Association for the Aid of Crippled Children, New York, U.S.A., the Swedish Medical Research Council, Uppsala and Svenska Nationalföreningen mot tuberkulos och andra folksjukdomar, Stockholm, Sweden.

\section{REFERENCES}

Astrup, P. (1956). A simple electrometric technique for the determination of carbon dioxide tension in blood and plasma. Scand. J. clin. Lab. Invest., 8, 33

, Jørgensen, K., Siggaard Andersen, O. and Engel, K. (1960) The acid-base metabolism; a new approach. Lancet, 1, 1035.

Beer, R., Bartels, H. and Raczkowski, H.-A. (1955). Die Sauerstoffdissoziationskurve des fetalen Blutes und der Gasaustausch in der menschlichen Placenta. Pflug. Arch, ges. Physiol., 260, 306.

Boutourline-Young, H. and Boutourline-Young, E. (1956). Alveolar carbon dioxide levels in pregnant, parturient and lactating subjects. J. Obstet. Gynaec. Brit. Emp., 63, 509.

Clemetson, C. A. B. and Churchman, J. (1953). Oxygen and carbon dioxide content of umbilical artery and vein blood in toxaemic and normal pregnancy. Ibid., 60, 335.

Darling, R. C., Smith, C. A., Asmussen, E. and Cohen, F. M. (1941) Some properties of human fetal and maternal blood. J. clin. Invest., 20, 739

Eastman, N. J. (1932). Foetal blood studies III. The chemical nature of asphyxia neonatorum and its bearing on certain practical problems. Bull. Johns Hopk. Hosp., 50, 39.

Goodlin, R. C. and Kaiser, I. H. (1957). The effect of ammonium chloride induced maternal acidosis on the human fetus at term I. pH, hemoglobin, blood gases. Amer. J. med. Sci., 233, 662 .

Haselhorst, G. and Stromberger, K. (1931). Uber den Gasgehalt des Nabelschnurblutes vor und nach der Geburt des Kindes und über den Gasaustausch in der Plazenta. Z. Geburtsh. Gynäk. $100,48$.

Henderson, L. J. (1928). Blood. A Study in General Physiology. Yale University Press, New Haven.
James, L. S., Weisbrot, I. M., Prince, C. E., Holaday, D. A. and Apgar, V. (1958). The acid-base status of human infants in relation to birth asphyxia and the onset of respiration. J.Pediat., $52,379$.

Jergensen, K. and Astrup, P. (1957). Standard bicarbonate, its clinical significance and a new method for its determination. clinical significance and a new met
Scand. . clin. Lab. Invest., 9, 122.

Kaiser, I. H. (1953). The hydrogen ion concentration of human fetal blood in utero at term. Science, 118, 29.

- (1959). The significance of fetal acidosis. Amer. J. Obstet. Gynec., 77, 573.

and Goodlin, R. C. (1958). The effect of ammonium chloride induced maternal acidosis on the human fetus at term: II induced maternal acidosis on the human
Electrolytes. Amer. J. med. Sci., 235, 549.

MacKay, R. B. (1957). Observations on the oxygenation of the foetus in normal and abnormal pregnancy. J. Obstet. Gynaec. Brit. Emp., 64, 185.

MacKinney, L. G., Goldberg, I. D., Ehrlich, F. E. and Freymann, K. C. (1958). Chemical analyses of blood from the umbilical cord of the newborn: Relation to fetal maturity and perinatal cord of the newborn: Relation
distress. Pediatrics, 21, 555 .

Noguchi, M. (1937). Jap. J. Obstet. Gynec., 20, 348. Cited by Kaiser, I. H.

Roos, J. and Romijn, C. (1940). Proc. kon. ned. Akad. Wet., 43, 1212 and 1311. (Cited by Young, 1952)

Rooth, G and Siöstedt, S. (1957a). Oxygen saturation in the umbilical vessels of the human foetus in normal and prolonged pregnancy. Acta obstet. gynec. scand., 36, 374.

- $(1957 \mathrm{~b})$. Haemoglobin in cord blood in normal and prolonged pregnancy. Arch. Dis. Childh., 32, 91 . , and Caligara, F. (10592). Oxygen tension measurements in whole blood with the Clark cell. Clin. Sci., 18, 379. , curve. Biol. neonat., 1, 61 .

Siggaard Andersen, O. and Engel, K. (1960). A new acid-base nomogram. Scand. J. clin. Lab. Invest., 12, 177.

Singer, R. B. and Hastings, A. B. (1948). An improved clinical method for the estimation of disturbances of the acid-base balance of human blood. Medicine (Baltimore), 27, 223.

Sjöstedt, S., Rooth, G. and Caligara, F. (1960). The oxygen tension of the blood in the umbilical cord and the intervillous space. Arch. Dis. Childh., 35, 529.

Walker, J. (1954). Foetal anoxia. J. Obstet. Gynaec. Brit. Emp., $61,162$.

Weisbrot, I. M., James, L. S., Prince, C. E., Holaday, D. A. and Apgar, V. (1958). Acid-base homeostasis of the newborn infant during the first 24 hours of life. J. Pediat., 52, 395.

Wulf, H. (1959a). Zur Diagnose der Neugeborenenapnoe. $Z$. Geburtsh. Gynäk., 152, 98.

- (1959b). Das Verhalten der Atemgase in den Nabelschnurgefässen nach der Geburt. Z. ges. exp. Med., 132, 136.

Young, I. M. (1952). $\mathrm{CO}_{2}$ tension across the placental barrier and acid-base relationship between fetus and mother in the rabbit. Amer. J. Physiol., 170, 434. 